\title{
PENGARUH OTORITAS KEAGAMAAN DI SEKOLAH ISLAM TERPADU
} THE INFLUENCE OF RELIGIOUS AUTHORITIES IN INTEGRATED ISLAMIC SCHOOLS

\author{
Solihah Titin Sumanti*, Zunidar, Hendra Kurniawan, Suryo Adi Sahfutra \\ Universitas Islam Negeri Sumatera Utara Medan, Jl. Willem Iskandar Pasar V Medan Estate 20371 \\ Sumatera Utara, Indonesia \\ *Corresponding author: solihahtitinsumanti@uinsu.ac.id
}

Naskah Diterima: 4 Maret 2020; Direvisi: 18 Mei 2020; Disetujui: 26 April 2021

\begin{abstract}
This study aims to show the tendency of urban Muslim communities in the city of Medan in choosing primary schools for children. The number of Islamic schools in Medan City continues to grow. The type of Islamic education that is developing is the Integrated Islamic School (SIT). SIT emerged as a response to the urban Muslim community. Its presence fulfills the wishes of previous Islamic education institutions, such as Islamic boarding schools, madrasas and public schools. The focus of the study looks at the role of the SIT religious authority in shaping teaching so that SIT's ability to compete with schools and Madrasahs affiliated with the NU, Muhammadiyyah, Al-Washliyah, and Al-Ittihadiyah organizations in terms of both curriculum and managerial aspects. The research method used is qualitative naturalistic. The main finding of this research is that the religious authority formed from the learning process at SIT leads to certain groups and ideologies affiliated with the Tarbiyah group. Its religious development indicates that the taste for Islamic education in urban communities leads to SIT which has an integrated curriculum. The managerial system is more modern in use because it is integrated with the existence of quality management in the administrative system that combines the managerial systems of the Ministry of Education and the Ministry of Religion, which are not owned by madrasah or pesantren institutions. The SIT curriculum model is successful in responding to the sociological needs of the urban Muslim community between the needs of religious and general teaching which is also a place to 'entrust' children all day because SIT uses a fullday curriculum model system.
\end{abstract}

Keywords: Intergrated Islamic School; Religious Authority; Urban Muslim

\begin{abstract}
Abstrak
Penelitian ini bertujuan untuk menunjukkan kecenderungan masyarakat muslim urban di kota Medan dalam memilih sekolah dasar bagi anak-anak. Jumlah sekolah Islam di Kota Medan terus berkembang. Jenis pendidikan Islam yang berkembang yaitu Sekolah Islam Terpadu (SIT). SIT muncul sebagai respon masyarakat muslim urban. Kehadirannya memenuhi keinginan yang tidak dimiliki lembaga pendidikan Islam sebelumnya, seperti pesantren, madrasah, dan sekolah umum. Fokus kajian melihat peran otoritas keberagamaan SIT dalam membentuk pengajaran hingga kemampuan SIT bersaing dengan sekolah dan Madrasah yang berafiliasi pada organisasi NU, Muhammadiyyah, Al-Washliyah, dan Al-Ittihadiyah dari segi kurikulum maupun managerialnya. Metode penelitian yang digunakan adalah kualitatif naturalistik. Temuan utama penelitian adalah otoritas keagamaan yang dibentuk dari proses belajar di SIT mengarah pada kelompok dan ideologi tertentu yang berafiliasi dengan kelompok Tarbiyah. Perkembangan keagamaannya mengindikasikan bahwa selera pendidikan Islam pada masyarakat urban mengarah pada SIT yang memiliki kurikulum integrasi. Sistem managerialnya lebih modern digunakan karena terintegrasi dengan adanya management quality pada sistem administrasi yang menggabungkan sistem managerial Kementerian Pendidikan dan Kementerian Agama, yang tidak dimiliki lembaga madrasah atau pesantren. Model kurikulum SIT berhasil merespon kebutuhan sosiologis masyarakat muslim urban antara kebutuhan pengajaran agama dan umum yang sekaligus menjadi tempat 'menitipkan' anak seharian karena SIT menggunakan sistem kurikulum model fullday.
\end{abstract}

Kata kunci: Masyarakat Muslim Urban; Otoritas Keagamaan; Sekolah Islam Terpadu 


\section{PENDAHULUAN}

Pada masa post-reformasi, perkembangan Islam mengalami perubahan yang begitu pesat bahkan belum pernah terjadi sebelumnya, termasuk ruang lingkup pendidikan Islam. Selama masa reformasi sistem pendidikan terus di bawah sistem sentralistik, maka setiap lembaga sekolah hanya mampu mencetak generasi yang tidak mampu mengembangkan kreativitasnya (Tilaar, 2002). Kualitas pelayanan pendidikan yang terjamin dengan tenaga pendidik terbaik, sarana dan prasarana yang menunjang dan lengkap, penguasaan bahasa asing, didukung oleh lingkungan pergaulan anak yang 'sederajat', merupakan beberapa harapan orang tua yang rela mengeluarkan biaya untuk pendidikan anakanaknya. Namun, semua itu tidak cukup bagi kaum muslim urban untuk merepresentasikan identitas dirinya melalui aspek keagamaan dan pola belajarnya. Perkembangan lembaga pendidikan Islam pada masa itupun seakan menjadi titik terang bahwa otoritas pemerintahan perlahan tidak berlaku lagi dan tergantikan dengan sistem demokrasi kerakyatan (Sa'dun, 2017).

Pada era tersebut perubahan yang cukup menarik adalah mengenai trend pendidikan (pendidikan Islam) di Indonesia. Lembaga pendidikan Islam terdiri dari Pesantren, Madrasah, dan sekolah umum yang perlahan mulai bergeser dengan populasi masyarakat muslim di kota-kota besar (Bryner, 2013). Hal ini mulai berubah semenjak muncul dan berkembangnya Sekolah Islam Terpadu (SIT). Didirikan pertama kali oleh para aktivis masjid kampus ITB dan UI, hingga lembaga pendidikan Islam ini tersebar ke seluruh wilayah Indonesia (Sofanudin, 2019). Pesatnya perkembangan SIT di kota-kota besar merupakan bukti bahwa sekolah ini menjadi tren baru pendidikan Islam di Indonesia. Dunia pendidikan juga ikut terpengaruh dengan trend budaya populer dengan sentuhan islami. Lembaga pendidikan berlomba menawarkan program pendidikan Islam dan berkelas. Di kota-kota besar muncul SIT yang dirintis di tahun 1990-an dan sangat diminati kaum urban muslim di kota Medan.

SIT adalah model lembaga pendidikan yang berupaya menggabungkan ilmu pengetahuan umum dan agama dalam ruang lingkup kurikulum terintegrasi. berbeda dengan tiga lembaga pendidikan sebelumnya, pesantren, madrasah dan dan sekolah umum (Raihani, 2012). Perkembangan lembaga pendidikan Islam pada waktu itu tampaknya menjadi titik terang bahwa otoritas pemerintah perlahan-lahan berhenti digantikan oleh sistem demokrasi populer. Termasuk dalam mengembangkan dan membangun institusi pendidikan Islam.

SIT lahir sebagai jawaban dari berbagai tuntutan dan permasalahan zaman serta merupakan mimpi dan harapan pemerintah dalam menyatukan dua ruh pendidikan menjadi satu kesatuan, yaitu menyatukan pendidikan umum dengan pendidikan keislaman. Lahir dan berkembangnya sekolah-sekolah Islam Terpadu di kota-kota besar di Indonesia beriringan dengan meningkatnya urbanisasi kaum muslim kelas menengah di kota. Hal ini dapat dilihat dari konsumen lembaga pendidikan tersebut yang mayoritas berlatar belakang keluarga dengan penuh aktivitas. Untuk itu, hadirnya sekolah Islam Terpadu merupakan jawaban yang dinanti-nanti oleh masyarakat urban muslim (Suyatno, 2013).

Faktor sosiologis juga menjadi pertimbangan penting mengapa dalam waktu 10 tahun terakhir mendapat sambutan luas dari masyarakat. Alasan secara sosiologis didasarkan pada seberapa jauh lembaga pendidikan dapat memenuhi peran-peran sosiologis, berupa kedudukan dalam kehidupan sosial dan pengakuan status sosial, serta meningkatkan prestise seseorang di masyarakat. Dengan memasukkan anak-anaknya di SIT secara tidak langsung dengan sendirinya mereka termasuk bagian dari kalangan menengah muslim.

Salah satu alasan kaum muslim urban menyekolahkan anaknya di SIT adalah kurang meyakini bahwa sekolah yang berada dibawah kementerian Agama, dianggap tidak mampu menjawab kemajuan dan tuntutan zaman. Untuk itu, masyarakat menghendaki adanya sebuah lembaga Pendidikan yang dapat memberikan bekal yang memadai bagi anak didik untuk menghadapi tantangan perkembangan zaman. Keterampilan berbahasa baik Arab dan Inggris dalam menunjang pengajaran keagamaan yang 
hampir mirip dalam membentuk pola pesantren dalam pengajaran keagaamannya menjadikan SIT ini juga kuat dalam pengajaran keagamaan (Soemanto, 2014). Perpaduan antara mata pelajaran umum dan mata pelajaran agama menjadi ciri khas dalam struktur kurikulum SIT ini. Kedua rumpun keilmuan tersebut samasama penting karena sama-sama mempelajari ayat-ayat Allah swt yang tertulis dalam teks Alquran dan Hadis, dan sisi lain rumpun keilmuan yang mempelajari ayat-ayat Allah swt berupa alam semesta (Jaringan Sekolah Islam Terpadu (JSIT) INDONESIA, n.d.).

Sekolah Islam Terpadu mengandung konsep "one for all”, yang mana peserta didik mendapatkan pendidikan umum, agama, dan keterampilan. Selain itu, sistem full day school dan boarding school juga merupakan salah satu yang ditawarkan oleh sekolah tersebut dengan landasan kurikulum yang bersumber dari kementerian pendidikan dan kebudayaan. Konsep "Sekolah Islam Terpadu" oleh para penggagasnya diupayakan untuk berada diantara kebijakan kementerian pendidikan dan kebudayan dan Kementerian Agama (Indonesia, 2013).

Penguasaan ilmu keagamaan yang dibutuhkan kaum urban muslim ditawarkan dalam lembaga pendidikan keagamaan (Islam) yang belum mampu menjawab kegelisahan atas kebutuhan simbol status sosial dan ekpresi modernitas (Azra, 1999). Seperti pondok pesantren sebagai salah satu model pendidikan Islam tertua di Indonesia. Model pesantren salafi dan modern sebagai dua jenis pesantren yang dikenal saat ini, juga belum mampu menjelaskan identitas kaum muslim urban. Ditambah lagi dengan sekolah bersistem madrasah yang memiliki muatan pelajaran agama Islam lebih dibandingkan pelajaran umum, terkadang sebagian orang tua menambah pengetahuan agama anaknya dengan mengaji di sore atau malam hari (Suyatno, 2013).

Fenomena ini, merupakan ekspresi dari orangtua yang belum puas dengan sistem pembelajaran di madrasah (Interview dengan Anton Huzali). Menjadi muslim yang taat juga harus menjadi pribadi yang akrab dengan segala kemajuan modernitas bahkan terlihat dalam penampilan gaya hidup, sehingga membahas soal kaum muslim urban harus mengacu pada definisi dan karakteristik khas yang mereka miliki (Dudin, 2017). Pada umumnya kehidupan kaum urban muslim mengacu pada mereka yang tinggal di kota-kota besar, memiliki modal kapital ekonomi, sosial dan budaya, berpendidikan tinggi-mereka adalah penganut agama Islam (modern) yang belakangan ini sedang berkembang.

Kurikulum SIT membawa Islamisasi kegiatan pendidikan di kelas (Suyatno, 2015). Dengan kata lain, standar kurikulum SIT bertujuan tidak hanya mengembangkan ilmu pengetahuan dan melengkapi mereka dengan kemampuan dan keahlian yang beriringan dengan penanaman moral keagamaan yang memperkuat keyakinannya terhadap agama Islam sehingga mereka berkomitmen untuk berdakwah. Klaim tersebut merupakan pondasi awal dari terbentuknya label 'Islam Terpadu', yang dicita-citakan dapat membentuk kepemimpinan muslim sehingga mempunyai keseimbangan pengetahuan agama dan sains.

SIT turut membangkitkan semangat keberislaman secara lebih terbuka dan membanggakan, yang pada gilirannya mempengaruhi geliat dakwah di masyarakat muslim dalam berbagai lapisan sosial ekonomi. Hadirnya SIT seakan mengindikasikan pergeseran pola belajar kaum muslim urban, terbukti dari nuansa kapitalisme pendidikan yang jelas terlihat dengan dana yang tidak murah harus dikeluarkan untuk bisa mengikuti pembelajaran ke sekolah ini, dengan penawaran sistem pembelajaran, gedung mewah, dan fasilitas yang memadai seakan menjelaskan bahwa pendidikan yang berkualitas itu harus mahal. Hal ini menegaskan bahwa SIT banyak diminati oleh kalangan muslim elit baik secara ekonomi, pendidikan, dan birokrasi.

Persoalan-persoalan diatas memunculkan kajian dalam tulisan ini berupa bagaimana otoritas pembelajaran keagamaan didapatkan dalam SIT yang ada di kota Medan, mulai dari sistem materi pendidikannya hingga sistem managerial yang mapan. Sehingga SIT dapat berkembang dengan baik di Kota Medan.

\section{KAJIAN TEORI}

Jika dilihat dari pengertian Muslim urban itu sendiri ialah berpasrah diri kepada Tuhan. 
Maksudnya ialah kaum muslim urban menyekolahkan anaknya di sekolah yang dapat memberikan bekal kepada anak-anaknya untuk dapat menghadapi tantangan zaman. Karena pada dasarnya adanya suatu kegelisahan orang tua terhadap pendidikan yang berada di bawah kementerian agama, di antaranya ialah madrasah dan pesantren. Di sini SIT muncul sebagai alternatif solusi belajar keislaman di perkotaan yang muncul dari keresahan masyarakat muslim urban yang menginginkan adanya lembaga pendidikan Islam tampil beda dari sebelumnya.

Kelompok-kelompok yang cukup menarik dibahas terutama di daerah perkotaan adalah kota Medan yang memiliki corak multikultur. Kota ini dikatakan sebagai pusat perubahan sosial yang memiliki tempat strategis untuk pertumbuhan dan perkembangan ekonomi, terutama di kalangan kelas menengah. Posisinya di tingkat menengah membuat status kelas ini menjadi penghubung antara kelas bawah dan kelas atas. Struktur sosial kelas menengah dapat digunakan sebagai sarana memberikan ide atau menunjukkan masalah yang berkembang terhadap pola keberagamaan masyarakat urban. Sebuah tesis yang menegaskan posisi kelas menengah sebagai jembatan antara kelompok kelas yang lebih tinggi dan kelas yang lebih rendah dapat menjadi target dan studi yang menarik, karena suatu budaya akan mudah diserap oleh kelompok ini yang kemudian mencerminkan sikap budaya. Kuntowijoyo percaya bahwa ada dua sikap budaya yang mungkin muncul. Pertama, budaya elit: pemiliknya tetap menjadi subjek budaya, tidak mengalami keterasingan dan mengalami kecerdasan (Kuntowijoyo, 2004). Pemilik budaya elit identitasnya tidak tenggelam dalam budaya. Kedua, budaya ini tidak berperan dalam pembentukan simbolsimbol budaya (Maksudin, 2010). Kelompok kelas menengah yang menjadi fokus penelitian di sini adalah kelompok yang secara ekonomi di atas rata-rata, yang tingkat mobilitas dan aksesibilitasnya cukup tinggi. Mereka adalah orang-orang yang rasional dan tinggal di kota, dan kebanyakan dari mereka mendapatkan pendidikan publik (bukan sekolah agama). Dalam hal pekerjaannya sebagai seorang profesional seperti pengusaha, dokter, karyawan, pengacara, dan lainnya.
Untuk kelas menengah Muslim urban, nilai-nilai spiritualitas agama harus memberikan nilai ketenangan, kenikmatan dan ketenangan untuk semua yang harus ditampilkan, tidak disembunyikan dan dimasukkan ke dalam nilai-nilai narsis. Karena itu, apa yang mereka perlihatkan adalah bagaimana menunjukkan identitas Muslim mereka dengan cara, model, dan gaya berpakaian. Ini juga merupakan bentuk eksistensi diri yang diketahui oleh masyarakat sekitarnya (Rofhani, 2013). Menunjukkan identitas spiritual tidak hanya masalah penerapan agama tetapi juga dapat dilihat dari pilihan pendidikan untuk anak-anak mereka dengan memilih sekolah Islam dengan fasilitas lengkap. Mereka memilih sekolah umum tetapi diberi label Islam, dan di lembaga ini mereka bertemu dan berkumpul untuk membentuk komunitas tersebut

Munculnya kelas menengah muslim adalah konsekwensi dari lajunya modernisasi dan globalisasi yang terus beradaptasi dengan prilaku keagamaan. Bagaimana pengaruh dua isu besar tersebut terhadap konstruksi keagamaan kelas menengah muslim dapat dilihat dari gaya hidup (life style). Identifikasi kelas menengah muslim dapat di lihat dari perspektif ekonomi, yaitu mereka yang tingkat pendidikannya minimal strata satu (S1). Kelompok ini biasanya lebih banyak di dominasi oleh mereka yang berlatar belakang pendidikan non keagamaan dan bekerja di tempat-tempat yang berpenghasilan lumayan seperti dokter, pengacara, pegawai eksekutif baik negeri maupun swasta dan lain-lain.

Fase selanjutnya adalah bersentuhannya gaya hidup dengan semangat kapitalisme yang jeli melihat peluang pasar. Tanpa disadari bahwa sering terjadi 'perselingkuhan' antara agama dengan kapitalisme dalam bentukbentuk 'produk premium' yang diperuntukkan bagi kelas menengah muslim. Jumlah penduduk muslim Indonesia yang mencapai $83 \%$, tentu menjadi penanda bahwa kelas menengah muslim memiliki angka yang cukup besar, begitu juga sebaliknya, kaum kelas bawah (miskin) juga besar.

Hal yang paling menonjol dari kelas menengah muslim adalah sikap narsistik dan hedonis. Kategori ini dapat dilihat dari 
kebiasaan mereka memilih tempat nongkrong, cara mereka mengisi hari liburan dan pilihan pemenuhan kebutuhan hidup sehari-hari yang di beli di pusat perbelanjaan modern dan yang terakhir adalah prilaku keagamaan yang memunculkan tradisi urban Sufism. Yaitu proses pemenuhan kebutuhan spiritualitas yang tidak dapat dilepaskan dari hal-hal yang sifatnya material. Munculnya kelompok hijabers misalnya, menjadi tipe tersendiri dari karakteristik keagamaan kelas menengah muslim perkotaan. Kelompok ini memiliki kecenderungan yang tidak terlalu mempersoalkan masalah khilafiyah dalam bidang fiqh, bahkan topik perdebatan mengenainya pun sering dihindari. Bagi mereka proses ritualisasi keagamaan yang dapat memberikan nilai ketenangan, ketentraman dan kebahagian harus dimunculkan ke publik. Para orang tua yang muncul di SIT pada umunya memiliki mayoritas hijabers dengan konsep hijabers syari'ah dalam menonjolkan "life style" sebagai trend yang digunakan dalam keseharian. Termasuk acara arisan di kafe-kafe yang banyak dilakukan para orang tua sebagai masyarakat urban (Interview dengan Dewi Sulistiya).

Narsisme keagamaan bagi kalangan kelas menengah muslim adalah sebuah kebutuhan tentang pentingnya eksistensi diri ditengah pergaulan dan kehidupan sehari-hari. Selain fenomena hijabers, zakat dan sedekah menjadi model paling terlihat sisi narsistiknya, yaitu dengan cara mengundang anak-anak yatimpiatu, kalangan dhuafa datang kerumahnya untuk mendapatkan zakat. Aktivitas keagamaan yang di unggah ke media sosial adalah bentuk pencarian eksistensi religiusitas yang paling banyak muncul seiring menjamurnya pengguna sosial media dengan segala bentuk jenisnya. Orang tua yang berada dengan kelas menengah sangat dekat dengan media sosial yang mampu mengekspresikan pola keberagamaan dalam kehidupan keluarganya. Sifat-sifat religius yang ekstrim tergambar dalam status sosial di dalam kehidupan keseharian masyarakat urban (Yusup, 2018).

Pilihan pendidikan bagi anak-anak khususnya pada level pendidikan dasar sampai pada pendidikan menengah atas dapat diidentifikai kemana arah kelas menengah muslim menjatuhkan pilihannya. Biasanya sekolah yang yang dipilih adalah sekolah Islam modern dengan konsep SIT atau sekolah umum tapi bercirikan islami yang memiliki fasilitas lengkap dengan biaya pendidikan yang tinggi. Dari pilihan-pilihan semua aktivitas tersebut terbentuk komunitas-komuntas elit yang berisi kelas menengah muslim yang memiliki antusiasme yang sama dalam proses pembelajaran anak-anaknya.

\section{METODOLOGI}

Penelitian ini adalah penelitian kualitatif yang memiliki beberapa karakteristik yaitu, pertama berlangsung dalam latar ilmiah (Bungin, 2001), kedua, peneliti adalah instrumen atau alat pengumpul data yang utama; ketiga analisis datanya dilakukan secara induktif. Secara filosofis sesuai dengan karakter data, teknik pengumpulan dan analisisnya mengacu pada pendekatan kualitatifnaturalistik (Muhajir, 2002), yakni penelitian yang dilakukan secara alami (natural setting) tanpa disengaja atau by setting, peneliti terjung langsung kelapangan melakukan observasi sekaligus wawancara secara mendalam kepada informan serta memahami semua aspek yang terjadi dilapangan tanpa saling terpisah.

Observasi dilakukan di beberapa tempat seperti: sekretariat Jaringan Sekolah Islam Terpadu (JSIT) Sumatera Utara, beberapa SIT dengan berbagai tingkatan jenjang pendidikan, seperti sekolah Islam terpadu di bawah naungan yayasan Perguruan Islam Nurul Azizi meliputi jenjang TK sampai SMA Islam Terpadu, SDIT Al Hijrah 2, SDIT Al Hijrah Medan, SMPIT AN NUR PRIMA MEDAN, SMPIT Al Hijrah, SMAIT Al Fityan. Wawancara dilakukan kepada masing-masing kepala sekolah, guru bidang studi agama, orang tua wali siswa dan beberapa siswa. Rentang waktu pengambilan data lapangan dilakukan selama tiga bulan Desember 2018 sampai februari 2019. Lokasi sekolah yang diobservasi oleh peneliti berada di wilayah kota Medan. Setidaknya ada sekitar 20 orang informan utama yang diwawancarai secara mendalam. Kemudian data-data tersebut dianalisis kedalam dua tahap, yaitu analisis data lapangan dan analisis setelah data terkumpul (Biklen, 1982). Sedangkan hasil yang diperolah pada tahap pertama berupa catatan lapangan (field note) (Guba, 1985). 
Hasil analisis data-data akan mengkerucut pada tahap kesimpulan sementara yang diperolah dari hasil obeservasi dan kajian dokumen dengan menggunakan model analisis induktif. Kemudian dikembangkan pada analisis tahap kedua, yaitu; analisis setelah data terkumpul berupa sintesa-sintesa sehingga memunculkan alur pemikiran yang sistematis.

\section{HASIL DAN PEMBAHASAN}

Sebagai upaya reintegrasi ilmiah dalam pendidikan Islam, kurikulum SIT merupakan bagian dari ideologi pendidikan yang diadopsi dari Ikhwanul Muslimin. Konsep muwașafat adalah tujuan dalam pendidikan yang diselenggarakan oleh sebuah SIT. Secara khusus, kurikulum SIT merupakan kurikulum yang memuat target-target pencapaian secara berkala di beberapa tingkatan yang mencakup pembelajaran pada anak-anak, remaja dan dewasa.

Konsep ini terintegrasi dalam proses belajar mengajar yang berlangsung di dalam kelas dan di luar kelas berdasarkan kurikulum. Selain itu, implementasi kurikulum dalam proses belajar mengajar juga didukung oleh guru yang mampu menjadi panutan bagi siswa. Struktur kurikulum SIT berisi tiga program, sebagai berikut: pertama, program reguler; kedua, program Islam Terpadu; dan ketiga program pengembangan diri. Oleh karena itu, kurikulum SIT bertujuan tidak hanya untuk mengembangkan pengetahuan dan membekali mereka dengan keterampilan kejuruan, tetapi yang lebih penting adalah mampu menanamkan nilai-nilai moral agama dan memperkuat kepercayaan mereka pada agama Islam. Kemampuan memiliki nilai-nilai moral adalah sebagai komitmen dakwah yang dapat diklaim sebagai perwujudan dari kata "Integrated atau Terpadu" pada sistem sekolah dengan fondasi kuat untuk pembentukan kepemimpinan Muslim masa depan.

Semua mata pelajaran terintegrasi dengan nilai-nilai moral Alquran dan Sunnah dengan ilmu-ilmu modern. Ini adalah alat yang sangat penting untuk menyeimbangkan siswa baik dari segi penguasaan ilmiah modern dan moralitas agama sehingga seluruh kehidupan siswa tampaknya hanya melayani Allah. Ada lima prinsip yang menjadi karakter kurikulum sekolah Islam Terpadu; (1) Pendidikan dan pembelajaran berbasis Islam di semua aspek kegiatan sekolah; (2) pembelajaran berbasis kompetensi; (3) Penguasaan Alquran; penguasaan bahasa Arab dan Inggris; (3) aktualisasi kemampuan dan bakat siswa (Sofanudin, 2019).

Di Sumatera Utara jumlah lembaga pendidikan dengan konsep Islam terpadu tergabung dalam Jaringan Sekolah Islam Terpadu (JSIT) Sumatera Utara. Hal ini karena label Islam terpadu sudah memiliki hak paten, sehingga sekolah-sekolah yang ingin menggunakan nama itu harus mengajukan permohonan ke JSIT sebagai badan pengelola. Berdasarkan data yang dihimpun penulis terdapat beberapa sekolah yang tergabung dalam Jaringan Sekolah Islam Terpadu seperti dalam jenjang Raudhatul Athfal terdapat 10, TK Islam Terpadu terdapat 19, SD Islam Terpadu terdapat 32, SMP Islam Teradu terdapat 13, dan SMA Islam Terpadu terdapat 3 sekolah.

Perkembangan SIT mampu memberikan corak baru dalam perkembangan islamisasi masyarakat Indonesia, khususnya masyarakat kota (Hasan, 2012). Proses santrinisasi tersebut berkembang melalui SIT yang dapat berlangsung melalui berbagai model. Pada umumnya para siswa di SIT banyak mengalami proses reislamisasi. Artinya, peserta didik mendapat didikan serta ajaran serta praktikpraktik keagamaan secara intens dan terstruktur (Interview dengan Suhendri).

Kegiatan-kegiatan ekstrakulikuler yang dilakukan dalam kerangka penanaman nilainilai keagamaan, secara langsung atau tidak langsung telah mempengaruhi kedalaman wawasan keislaman anak didik. Selain itu, para siswa di SIT mendapat tugas keagamaan tambahan yaitu membawa pulang ke rumah masing-masing dan melibatkan anggota keluarganya dalam pengetahuan dan praktik keislaman yang dikerjakannya (Interview dengan Suhendri). Mayoritas SIT melakukan semacam konsekuensi dengan orang tua siswa dalam hal proses pembelajaran (setiap bidang studi pengembangan) yang harus diikutsertakan dalam memantau anaknya di rumah (Interview dengan A. Pasaribu). Walaupun 'pangsa pasar' Sekolah Islam terpadu adalah kelas menengah yang secara umum memiliki pekerjaan 
professional. Namun, proses pembelajaran yang dilakukan di banyak SIT melibatkan orang tua baik bidang kegamaan hingga bidang sains dan teknologi.

Keberadaan SIT di tengah masyarakat tidak hanya melakukan islamisasi di lembaga pendidikan formal saja, namun juga berdampak langsung terhadap perkembangan keislaman di masyarakat umum. Hal ini merupakan konsekuensi logis dari manajemen SIT yang memang melibatkan pihak-pihak luar sekolah (masyarakat dan orang tua) untuk dapat bersinergi dengan SIT dalam melakukan integrasi dan keikutsertaan antar berbagai pihak luar sekolah untuk bersama-sama melakukan perubahan dalam bidang pendidikan.

Fakta lain dari kehadiran SIT sebagai lembaga pendidikan, merupakan jawaban atas anggapan bahwa pendidikan Islam itu tidak selalu identik dengan tradisional saja. Adanya SIT merupakan bukti bahwa pendidikan Islam mampu tampil dan berbicara soal sains dan teknologi yang saat ini mampu bersaing dengan sekolah-sekolah umum kejuruan lainnya. Hadirnya SIT juga membangkitkan semangat belajar Islam bagi masyarakat dan orang tua secara lebih terbuka dan jelas, dan pada saatnya mempengaruhi kegiatan dakwah di masyarakat muslim kota dalam berbagai lapisan sosial ekonomi. Hal ini mempertegas bahwa SIT diminati oleh kalangan Muslim elit baik dalam arti secara ekonomi, keterdidikan, dan birokrasi (Alam, 2017). Artinya, pola baru santrinisasi muncul di kalangan kelas menengah muslim. Pola dakwah ini berbeda dengan pola pada umumnya yang dilakukan di masjid-masjid, dan tempat kegiatan keagamaan lainnya.

Jejaring kelompok penopang SIT sangat solid, yakni kelompok Tarbiyah yang memiliki jaringan dari kelompok elit hingga kelompok terbawah. Implikasi kesalehan sosial yang menarik minat kelompok muslim urban sampai pada keberhasilan dalam mendidik anak-anak tampil relijius dengan menguasai ajaran Islam secara normatif. Sementara itu dari aspek tantangan, kecenderungan terjadinya konflik internal dalam pengelolaan, maka sering memunculkan lembaga SIT baru ditempat lain (Embong, 2011).

Perkembangan SIT pada level sekolah dasar (SD) dan sekolah Menengah Pertama
(SMP) dan sekolah Menengah Atas (SMA) di kota Medan mengalami perkembangan yang signifikan, hal itu dapat dilihat dari munculnya sekolah-sekolah baru atau pun lama yang bermetamorfosis dalam label 'Islam Terpadu'. Label ini bukan sekedar menempelkan kata Islam pada nama sekolah, namun sekolahsekolah dengan label Islam Terpadu memiliki ciri khas tersendiri dibandingkan dengan sekolah Islam yang lain sejenis madrasah dan bahkan pesantren. Hal ini yang membuat SIT dapat tumbuh dan berkembang secara masif dalam satu dekade terakhir adalah pertanyaan yang penting untuk diuraikan.

SIT mengutamakan pelayanan secara keseluruhan, padahal notabenenya setiap Lembaga Pendidikan memiliki keunggulan yang berbeda-beda. Namun hal ini yang menjadi salah satu alasan utama bagi orang tua untuk mempercayai dan menyekolahkan anaknya di SIT, bahkan rela mengeluarkan dana besar untuk dapat belajar secara formal di sekolah ini. Dengan demikian, baik sekolah umum, madrasah, bahkan pesantren memiliki pola didik yang berbeda. Contoh yang paling mendasar misalnya, pesantren yang membiasakan santrinya untuk mandiri dan mahir dalam keagamaan. Sedangkan di SIT diajarkan kemandirian, pembentukan karakter, keagamaan, dan ilmu-ilmu sains lainnya.

Pertanyaan pertama yang dibahas yaitu tentang bagaimana sekolah Islam Terpadu di kota Medan berkembang secara masif. Analisis dasar sebagai pondasi dalam mengurai faktor perkembangan harus dimulai dari tesis bahwa masyarakat Indonesia khususnya Medan pasca runtuhnya rezim orde baru, diiringi dengan laju globalisasi yang tidak terbendung membuka sekat informasi yang selama ini diproteksi oleh rezim penguasa akan melahirkan masyarakat modern dan sekuler. Artinya, masyarakat akan melihat peluang dalam bidang sains dan tekonologi atau yang dikenal dengan IPTEK.

Pada fase awal reformasi, gejala semacam itu sempat terlihat, dugaan bahwa Pendidikan Islam akan tergerus oleh perkembangan teknologi, karena sekolah Islam dikesankan tradisional dan terbelakang dalam bidang penguasaan teknologi, maka sekolah yang demikian akan banyak ditinggalkan oleh masyarakat yang membutuhkan pengetahuan 
yang tidak hanya dalam bidang keagamaan semata. Ternyata secara perlahan tesis itu mulai terbantahkan, geliat sekolah Islam sejak awal tahun 2000-an yang tadinya tidak terlihat setelah 15 tahun lebih mulai menyita banyak perhatian publik.

SIT menangkap dua kegelisahan masyarakat kota, khususnya kalangan kelas menengah tentang pentingnya sekolah yang dapat memberikan pengetahuan modern bagi anak-anak seperti penguasaan sains, bahasa dan lainnya, tapi pada saat yang bersamaan tidak meninggalkan aspek keagamaan. karena bagaimanapun masyarakat Indonesia adalah masyarakat religius. Dasar ini kemudian memunculkan ide tentang konsep Islam Terpadu. Perpaduan antara penguatan ilmu pengetahuan modern dan ilmu agama secara bersamaan.

Gejala ini ditangkap oleh kalangan aktivis kota yang tergabung dalam kelompok Tarbiyah yang sulit rasanya disangkal mereka terafiliasi dengan partai Islam seperti Partai Keadilan Sejahtera (PKS). Kader-kader Tarbiyah merasakan kegelisahan akan situasi pendidikan di Indonesia yang menurut pemahaman mereka tertinggal dalam bidang sains dan agama secara bersamaan. Kalaupun maju dalam bidang sains tapi minus dalam bidang keagamaan, atau ahli dalam bidang keagamaan tapi minus dalam bidang sains, begitu juga jika terlebih model pendidikan Islam yang tersedia tidak cocok dengan 'selera' ideologis kelompok ini.

Jaringan Tarbiyah ini sangat ideologis, faktor ini yang melahirkan militansi dalam pengembangan SIT, meskipun tidak semua SIT di kota Medan terafiliasi dengan jaringan Tarbiyah, namun kemunculan awal sulit ditolak keterlibatan jaringan ini. Jejaring ini bekerja dalam merumuskan sistem sekolah, mulai dari pola manajemen, proses KBM, hingga proses rekrutmen tenaga pengajar. Bahkan pada awalnya siswa juga bagian dari jaringan ini. Jejaring Tarbiyah ini kemudian membentuk asosiasi SIT dengan nama Jaringan Sekolah Islam Terpadu (JSIT) di bawah asosiasi ini kemudian sinergisitas, kesinambungan dan berbagai persoalan yang dihadapi sekolahsekolah Islam Terpadu dirumuskan dan dibahas untuk dicarikan solusi jalan keluar (Masruri, 2016).
Hal tersebut secara tegas tertulis dalam anggaran dasar dan sesuai Anggaran Dasar JSIT Indonesia Pasal 7, yaitu sebagai penggerak mempelopori pemberdayaan SIT di Indonesia menuju sekolah efektif dan bermutu, mengkoordinasikan program kerjasama antaranggota JSIT Indonesia, melakukan penilaian, pengawasan, dan pembinaan penyelenggaraan dan pengelolaan sekolah bagi anggota JSIT Indonesia, melakukan pembelaan untuk umat Islam di bidang Pendidikan, melakukan aktivitas melayani, membantu, dan memfasilitasi kebutuhan anggota Jaringan SIT, serta melakukan penelitian dan pengkajian bidang pendidikan bagi pengembangan sekolah-sekolah yang menjadi anggota Jaringan Sekolah Islam Terpadu (Jaringan Sekolah Islam Terpadu (JSIT) INDONESIA, n.d.).

Daya dukung finansial cukup penting dalam mengembangkan lembaga pendidikan swasta, karena basis sekolah ini adalah terpadu, maka tidak heran biaya pendidikan yang dibebankan kepada orang tua murid juga mahal. Hampir bisa dipastikan mereka mayoritas yang menyekolahkan anaknya di SIT berasal dari kalangan kelas menengah ke atas. Rata-rata orang tua harus mengeluarkan biaya sekitar 510 juta untuk biaya awal masuk.

Biaya pembangunan untuk pertama kali masuk di sekolah Islam terpadu yang tergabung dalam JSIT berkisar antara Rp. 5.000.00010.000.000, sedangkan iuran perbulanya sebesar Rp. 500.000-1.000.000, termasuk dana snack dan makan siang yang disediakan oleh sekolah. Tingginya biaya untuk kebutuhan SIT karena sistem sehari penuh atau dikenal dengan istilah fullday school. Selain itu harus diakui jaringan sekolah ini memang menyasar kelompok kelas muslim urban. Tingginya biaya selain karena sistem sekolah seharian, faktor lain karena adanya praktik ekstrakurikuler yang padat yang membutuhkan biaya yang tidak murah. Kegiatan ekstra bisa disesuaikan dengan minat dan bakat siswa, tapi lebih sering agendaagenda bernuansa keagamaan berbasis ketarbiyahan.

SIT menyasar kelas menengah muslim urban sebagai basis daya dukung bagaimana sekolah ini berkembang dengan pesat. Dari segi finansial kelas menengah muslim tidak ragu mengeluarkan dana besar bagi biaya pendidikan 
selama karakter SIT terpadu sesuai dengan karakteristik kelas menengah umumnya, yakni, ketersediaan fasilitas yang bagus, sistem manajemen, pelayanan dan kualitas dalam bidang sains dan agama. Seperti yang diuraikan oleh Suprato terkait dengan kurikulum misalnya, banyak sekolah berbasis Islam terpadu mencoba memadukan kurikulum nasional dengan kurikulum yang dibangun oleh JSIT (Suprapto, 2014). Kekhasan kurikulum dalam sistem JSIT terletak pada kemampuannya beradaptasi dengan konteks lokal, ianya adaptif tidak hanya terhadap kurikulum nasional, tapi nilai-nilai lokal yang berkaitan dengan moralitas misalnya menjadi bagian dalam kurikulum pembalajaran, apakah dalam bentuk pengajaran kelas formal atau dalam program ekstrakurikuler (Nuriyanto, 2014).

Aspek ideologis yang paling sering disorot dari keberadaan SIT ternyata tidak seragam dalam praktiknya, karena pendirian sekolah tidak serta merta berlatar belakang ideologi keagamaan yang sama (Suharto, 2018), prosedurnya masih banyak bernuansa administratif, meskipun dominan dari haluan ideologi, namun faktanya banyak SIT berbeda secara ideologis (Sofanudin, 2019). Hal ini karena JSIT tidak kaku menerapkan agenda ideologi kedalam kurikulum khusus yang mereka bangun, mereka sadar betul aspek pragmatisme menjadi hal penting dalam roda perjalanan lembaga.

\section{PENUTUP}

Studi ini menjelaskan bahwa otoritas keagamaan di bidang pendidikan Islam bergeser ke tengah-tengah masyarakat kelas Muslim Urban. Ini karena selera kelas menengah Muslim untuk pendidikan lebih fokus pada kombinasi pendidikan agama dan umum. Sebagai masyarakat urban, cita rasa pendidikan ini direspon oleh para praktisi pendidikan dengan menghadirkan pendidikan Islam Terpadu. Konsep pendidikan Islam Terpadu sesuai dengan selera kelas yang dimenangkan, yaitu fasilitas yang baik, layanan yang sangat baik, kurikulum yang diharapkan dan manajemen kualitas yang baik serta sumber daya yang berkualitas.
Perkembangan SIT cukup tinggi di kota Medan. Situasi psikologis masyarakat kota yang menghadapi dilema spiritual akibat ketidakpastian modernisasi dan globalisasi memiliki tempat untuk meninggalkan anakanak mereka untuk para ahli di bidang sains serta di bidang agama. Karakter ini khas menjadi orientasi masyarakat muslim urban, cara berpikir yang praktis sekaligus pragmatis dalam beragama sekaligus hal-hal yang bersifat duniawi. Pada titik ini pergeseran otoritas keagamaan akan merujuk kepada kelompok yang juga memiliki orientasi yang sama yakni rigit dalam melihat ajaran Islam sekaligus kaku dalam pelaksanaannya.

Penelitian ini mencoba memberikan saran terkait pengambil kebijakan, khususnya bidang pendidikan Islam agar menjadi payung yang mampu membingkai keragaman orientasi sekolah-sekolah yang ada di Indonesia untuk menjadikan konsensi negara bangsa sebagai sesuatu yang baku kedalam kurikulum semua pendidikan. Selain itu, skala pembatasan kurikulum khas lembaga tertentu harus menjadi perhatian serius terkait aspek ideologi yang biasanya tersembunyi.

\section{UCAPAN TERIMAKASIH}

Penulis mengucapkan banyak terima kasih kepada semua pihak yang telah memberikan berkontribusi pada penelitian ini. Pertama kepada kepala puslitbang pendidikan agama dan keagamaan, Badan litbang dan Diklat, Kementerian Agama RI. Kedua kepada rekan dosen STAI Sabili Bandung yang telah mendukung dan membantu dalam pelaksanaan penelitian ini. Ketiga kepada kepala sekolah SMK Negeri Negeri 1 Rajadesa Kecamatan Rajadesa Kabupaten Ciamis, yang telah memberikan izin kepada penulis untuk melakukan penelitian di sekolah tersebut, semua guru, tenaga kependidikan serta segenap siswa yang telah memberikan data dan informasi kepada penulis. Semoga penelitian ini memberikan manfaat bagi semua pihak dalam rangka peningkatan mutu tenaga pendidik di SMK Negeri 1 Rajadesa Kecamatan Rajadesa Kabupaten Ciamis.

\section{DAFTAR PUSTAKA}

Alam, L. (2017). Becoming Modern Muslim: New Emerging Trends of Islamic Schools 
in Yogyakarta. Journal of Islamic Education, 22(1), 75-86. https://doi.org/10.19109/TD.V22I1.1331

Azra, A. (1999). Pendidikan Islam: Tradisi dan Modernisasi Menuju Milenium Baru. Logos Wacana Ilmu.

Biklen, S. (1982). Qualitative Research For Education: An Introduction to Theory and Methods. Allyn and Bacon Inc.

Bryner, K. (2013). Piety Projects: Islamic Schools for Indonesia's Urban Middle Class. https://doi.org/10.7916/D8V69RR7

Bungin, B. (2001). Metodologi Penelitian Kualitatif Aktualisasi Metodologis ke Arah Ragam Varian Kontemporer. Rajawali Press.

Dudin, A. (2017). Management Policy of PAI Lecturer: Case Study at The Campus of UGM Yogyakarta. Dialog, 40(2), 173186.

https://doi.org/10.47655/dialog.v40i2.18 8

Embong, R. (2011). The Concept of Islamic Integrated Curriculum (IIC): Implications for Islamic Schools. Kuala Lumpur: Institute of Education, International Islamic University Malaysia, 2011. http://studentrepo.iium.edu.my/handle/12 $3456789 / 4142$

Guba, E. G. (1985). Naturalistic inquiry. Sage Publication Inc.

Hasan, N. (2012). Education, Young Islamists and Integrated Islamic Schools in Indonesia. Studia Islamika, 19(1). https://doi.org/10.15408/sdi.v19i1.370

Indonesia, T. J. (2013). Membangun Pendidikan Bermutu Melalui Sekolah Islam Terpadu. JSIT Indonesia.

Jaringan Sekolah Islam Terpadu (JSIT) INDONESIA. (n.d.). Retrieved April 13, 2021, from https://jsit-indonesia.com/

Kuntowijoyo. (2004). Budaya Elite dan Budaya Massa. Jalasutra.

Maksudin. (2010). Pendidikan Islam Alternatif, Membangun Karakter Melalui Sistem
Boarding School. UNY Press.

Masruri, E. (2016). Membangun Paradigma Baru Pendidikan Islam Terpadu. JSIT Yogyakarta.

Muhajir, M. (2002). Metode Penelitian Kualitatif. Andi Offset.

Nuriyanto, L. K. (2014). Model Kurikulum Pendidikan Agama Islam di SDIT alAnwar dan Firdaus Mojokerto Jawa Timur. EDUKASI: Jurnal Penelitian Pendidikan Agama Dan Keagamaan, 12(1), 15-25.

Raihani, R. (2012). Islamic Schools and Social Justice in Indonesia: A Student Perspective. Al-Jami'ah: Journal of Islamic Studies, 50(2), 279-301. https://doi.org/10.14421/ajis.2012.502.27 9-301

Rofhani, R. (2013). Pola Religiositas Muslim Kelas Menengah di Perkotaan. Religió: Jurnal Studi Agama-Agama, 3(1), 65-66. http://jurnalfuf.uinsby.ac.id/index.php/rel igio/article/view/462

Sa'dun, S. (2017). Model Manajemen Pendidikan Islam Terpadu dalam Upaya Peningkatan Mutu Sekolah (Studi Kasus di Yayasan Bina Insani Purwodadi Tahun Pelajaran 2014/2015). QUALITY, 4(2), 228-245.

https://journal.iainkudus.ac.id/index.php/ Quality/article/view/2122

Soemanto, S. (2014). Pendidikan Agama Islam Terpadu pada SMPIT Bina Umat Yogyakarta. EDUKASI: Jurnal Penelitian Pendidikan Agama Dan Keagamaan, 12(2), 247-260. https://doi.org/10.32729/edukasi.v12i2.8 6

Sofanudin, A. (2019). Curriculum Typology of Islamic Religion Education in Intergrated Islamic School (SIT). EDUKASI: Jurnal Penelitian Pendidikan Agama Dan Keagamaan, 17(1). https://doi.org/10.32729/edukasi.v17i1.5 63

Suharto, T. (2018). Transnational Islamic education in Indonesia: an ideological perspective. Contemporary Islam, 12(2), 
101-122. https://doi.org/10.1007/s11562017-0409-3

Suprapto, S. (2014). Model Pembelajaran Pendidikan Agama Islam Terpadu Di Sma-it Darul Hikam Bandung. EDUKASI: Jurnal Penelitian Pendidikan Agama Dan Keagamaan, 12(1), 27-41.

Suyatno, S. (2013). Sekolah Islam terpadu; Filsafat, ideologi, dan tren baru pendidikan Islam di Indonesia. Jurnal Pendidikan Islam, 2(2), 355-377. https://doi.org/10.14421/jpi.2013.22.355377

Suyatno, S. (2015). Sekolah Islam Terpadu dalam Sistem Pendidikan Nasional. AlQalam, 21(1), 1-10. https://doi.org/10.31969/alq.v21i1.213

Tilaar, H. A. R. (2002). Membenahi pendidikan nasional. PT Rineka Cipta.
Yusup, M. (2018). Ekskluvisme Beragama Jaringan Sekolah Islam Terpadu (JSIT) Yogyakarta. RELIGI JURNAL STUDI AGAMA-AGAMA, 13(01), 75. https://doi.org/10.14421/rejusta.2017.130 1-05

\section{Daftar Informan:}

Dewi Sulistiya, tanggal wawancara 10 Januari 2019, (Orang Tua Murid).

Anton Huzali, tanggal wawancara 4 Februari 2019, (Orang Tua Murid).

Suhendri, tanggal wawancara, 2 Agustus 2019, (Pengurus JSIT Sumut).

Pasaribu, tanggal wawancara 2 September 2019, (Orang Tua Murid). 